\title{
Pencegahan terhadap Pelanggaran Hak Perempuan Sebagai Pekerja berdasarkan Undang-Undang Nomor 13 Tahun 2003
}

\author{
Hesti Widyaningrum ${ }^{1}$ \\ Universitas Bhayangkara Jakarta Raya, kotak_violet@yahoo.com \\ Irma Setyawati ${ }^{2}$ \\ Universitas Bhayangkara Jakarta Raya, s_etyawati@yahoo.com \\ Yatty Maryati Azhari3 \\ Universitas Bhayangkara Jakarta Raya, yatty_azhary@yahoo.co.id
}

\begin{abstract}
Abstrak
Kegiatan pengabdian kepada masyarakat ini bertujuan untuk memberikan informasi terkait dengan pelanggaran hak perempuan sebagai pekerja berdasarkan Undang-Undang Nomor 13 Tahun 2003. Kegiatan ini berupa penyuluhan kepada 40-50 orang pekerja perempuan di PT. Prakarsa Alam Segar (PAS), Bekasi, karena peningkatan kapasitas produksi sangat dibutuhkan dalam memenuhi kebutuhan pasar baik dalam skala nasional maupun global. Kebutuhan terhadap jumlah tenaga kerja tidak hanya pada pekerja laki-laki akan tetapi juga pada perempuan. Peningkatan tersebut, mestinya seiring meningkatnya proteksi hak pekerja perempuan dalam hubungan industrial. Dari kegiatan pengabdian kepada masyarakat diharapkan tenaga kerja perempuan memperoleh haknya sesuai dengan Undang-Undang Nomor 13 Tahun 2003. Secara normatif hak pekerja perempuan telah dipenuhi oleh pihak perusahaan sebagaimana diatur dalam perjanjian kerja bersama mereka.

Kata Kunci: Hubungan Industrial, Pelanggaran Hak Perempuan, Undang-Undang Nomor 13 Tahun 2003
\end{abstract}

\section{Abstract}

Community service activity aims to provide information related to violations of women's rights as workers under Law Number 13 Year 2003. This activity is in the form of counseling to 40-50 women workers in PT. Prakarsa Alam Segar (PAS), Bekasi, due to increased production capacity is needed to meet market needs both nationally and globally. The need for manpower is not only for male workers but also for women. Such increase should be in line with the increasing protection of the rights of women workers in industrial relations. From the activity of dedication to the society, it is expected that women workers will have their rights in accordance with Law Number 13 Year 2003. Normatively the rights of women workers have been fulfilled by the companies as stipulated in their collective labor agreements.

Key word: Prevention, Right, Women Worker

\section{Pendahuluan}

Industrialisasi semakin berkembang bukan hanya negara-negara di Eropa tetapi juga negara-negara di Asia (Suryadi, 2016). Pertumbuhan industri biasanya 


\section{JURNAL ABDIMAS UBJ}

sama dengan pertumbuhan jumlah tenaga kerja. Banyak industri yang ada tidak hanya membutuhkan kemampuan dari laki-laki semata, melainkan juga ada beberapa industri membutuhkan kemampuan pekerja perempuan dalam sistem produksi mereka, semisal pabrik garmen.

Banyaknya perempuan yang bekerja di industri, terlihat dalam data Biro Pusat Statistik (BPS). Pada tahun 2016, terdapat 50,11 \% perempuan yang bekerja di berbagai perusahaan di Indonesia (Kementrian Perlindungan Pemberdayaan Perempuan dan Anak Republik Indonesia, 2013). Data di atas menunjukkan, bahwa perempuan punya peran dalam proses produksi di suatu industri. Setiap pelaksanaan kewajiban yang dilakukan oleh pekerja perempuan, memiliki hak atas perlindungan atas dirinya dari hal yang dapat mengancam keselamatan dan kesehatan organ fungsi reproduksinya (Undang-Undang Hak Asasi Manusia, 1999). Hak tersebut diatur dalam Undang-Undang Nomor 13 Tahun 2003 tentang Ketenagakerjaan (UUK). Beberapa hak tersebut antara lain, yakni, libur haid, hamil, melahirkan, keguguran, menyusui, dan penyediaan kendaraan untuk antar dan jemput bagi mereka yang bekerja malam hari.

Prakteknya, ketentuan di atas sering kali dilanggar oleh perusahaan. Seperti contoh yang diberitakan dalam salah satu media bahwa kasus sebuah pabrik di Karawang, perusahaan bukannya memenuhi hak cuti kepada 3 (tiga) pekerja perempuan yang hamil, akan tetapi pekerja tersebut diberhentikan oleh perusahaan, dengan dalih efisiensi dan pemutusan hubungan karyawan (PHK) tersebut dilakukan tanpa pesangon (imk/fjp, 6 Februari, 2015). Selain itu juga, kasus di Sumedang mengalami hal yang sama, di mana pekerja yang hamil dipaksa mengajukan pengunduran diri sehingga bersengketa di Pengadilan Hubungan Industrial Jawa Barat (putusan Mahkamah Agung Nomor 94K/Pdt.Sus/2013). Kasus di Kerinci, Jambi di mana beberapa pekerja perempuan perkebunan sawit yang tidak diberikan cuti haid oleh perusahaan ditempat dia bekerja. Terakhir kasus pelanggaran juga dialami oleh pekerja perempuan di Pelalawan, Pekanbaru di mana suatu perusahaan pupuk swasta tidak memberikan cuti haid bagi pekerja perempuan (Johanes, 2 Mei, 2013).

Hak perkerja perempuan di atas bertujuan untuk melindungi perempuan dari resiko terganggunya fungsi reproduksi (Darwin dan Wijaya, 1994). Sedangkan hak untuk menyusui bagi pekerja perempuan, tidak hanya bertujuan untuk memberikan makan kepada si bayi, melainkan juga untuk meningkatkan hubungan psikologi antara ibu dan anak. Walaupun begitu, perusahaan masih melakukan pelanggaran terhadap hak tersebut, padahal Undang-Undang Ketenagakerjaan telah melarang dengan tegas bagi setiap perusahaan yang tidak memenuhi hak-hak mereka. Pelanggaran ini berakibat pidana bagi pengusaha berupa pidana denda, kurungan, hingga penjara tergantung hak pekerja mana yang dilanggar oleh perusahaan (Undang-Undang Ketenagakerjaan, 2003). Larangan tersebut kemudian dipertegas kembali dalam Peraturan Menteri Tenaga Kerja Republik Indonesia Nomor : Per-03/MEN/1989 bahwa setiap pemberi kerja (perusahaan) tidak dibenarkan memutus hubungan kerja dengan alasan pekerja tersebut menikah, hamil, dan 


\section{JURNAL ABDIMAS UBJ}

melahirkan. Peraturan-peraturan diperuntukkan untuk melindungi perempuan baik dalam segi sosial, tekhnis, dan ekonomis (Asyhadie, 2007).

Perusahaan melakukan pelanggaran terhadap hak mereka, demi mendapatkan keuntungan semata dan masih rendahnya kesadaran untuk taat hukum sebagaimana disampaikan oleh Asisten Deputi Perlindungan Hak Perempuan dalam ketenagakerjaan di Kementrian Pemberdayaan Perempuan dan Perlindungan Anak (HN, 29 April, 2017).

Pelanggaran-pelanggaran tersebut dapat ditekan jika, pemerintah lebih meningkatkan perannya dalam menjamin dipenuhinya hak mereka. Kenyataannya, Tuntutan ini sering disuarakan dalam momen demonstrasi-demonstrasi pekerja perempuan seperti misalnya dalam peringatan hari Internasional women's Day beberapa bulan lalu, yang dijadikan kesempatan bagi mereka dalam penuntutan haknya sebagai perempuan dalam suatu perusahaan. Salah satu tuntutannya mendorong agar pemerintah lebih memaksimalkan pengawasan dan bertindak tegas bagi pengusaha yang belum memenuhi hak mereka ( Febriani, 2 Maret, 2017).

Selain itu juga, pemerintah dapat melakukan upaya preventif terhadap potensi terjadinya pelanggaran dengan meningkatkan pengetahuan pekerja perempuan, khususnya hak sebagai pekerja perempuan. Seperti yang disebutkan oleh Peneliti Senior Puslit Kependudukan Lembaga Ilmu Pengetahuan Indonesia dalam media Republika (Kualitas Tenaga Kerja Indonesia Masih Rendah, 17 September, 2017), bahwa 75\% dari pekerja di Indonesia hanya berpendidikan terakhir Sekolah Dasar (SD).

Upaya preventif ini tidak hanya dapat dilakukan oleh pemerintah, tetapi para akademisi dapat berperan dalam rangka mewujudkan Tridharma Perguruan Tinggi dengan cara meningkatkan pengetahuan terhadap pekerja perempuan, khususnya pengetahuan hukum terhadap hak-haknya sebagai pekerja. Peran para akademisi tersebut dapat dilakukan dengan cara sosialisasi atau penyuluhan hukum terhadap pekerja perempuan.

Tujuan kegiatan pengabdian kepada masyarakat untuk memberikan penyuluhan tentang hak perempuan sebagai pekerja yang harus dipenuhi oleh perusahaan dan untuk mengetahui dampak bagi pekerja perempuan yang tidak terpenuhi haknya oleh perusahaaan. Dengan demikian, kegiatan ini dapat meningkatnya pengetahuan mengenai hak bagi perempuan sebagai pekerja dan mencegah terjadinya dampak bagi pekerja perempuan yang haknya tidak dipenuhi oleh perusahaan.

\section{Metode Pelaksanaan}

Kegiatan pengabdian kepada masyarakat ini dilaksanakan pada tanggal 18 Desember 2017, disampaikan kepada 71 orang pekerja perempuan di PT. Prakarsa Alam Segar (PAS), Bekasi. Pelaksanaan kegiatan ini menggunakan metode penyuluhan dengan menyampaikan materi yang terkait dengan hak perkerja perempuan berdasarkan Undang-Undang Ketenagakerjaan.

Untuk mengetahui tingkat pemahaman peserta penyuluhan terhadap materi yang disampaikan, dilakukan pretest dan posttest. Hal ini diperlukan agar pelaksanaan dari penyuluhan ini dapat berjalan dengan efektif. Materi yang 


\section{JURNAL ABDIMAS UBJ}

disampaikan terkait dengan hak perempuan sebagai pekerja, dan dampak pelanggaran hak perempuan sebagai pekerja oleh perusahaan dapat dipahami oleh peserta.

\section{Hasil Pelaksanaan Pengabdian Kepada Masyarakat}

Kegiatan pengabdian ini telah dilaksanakan pada tanggal 8 Desember 2017 di PT. Prakarsa Alam Segar, Bekasi. Pelaksanaan kegiatan pengabdian dilakukan di ruang Pelatihan kerja PT. PAS yang diikuti sebanyak 71 peserta. Waktu kegiatan dilakukan pada pukul 15.30-18.00. Waktu ditentukan atas pertimbangan tidak mengganggu jam kerja pekerja yang sangat terbatas.

Ada beberapa catatan dari kegiatan yakni:

1. Jumlah peserta mengalami peningkatan sebanyak 21 peserta laki-laki.

2. Jumlah sasaran pekerja perempuan hanya 15 dari 50 peserta (Jumlah dari sasaran awal), sedangkan sebagian lainnya disi oleh pekerja laki-laki. Hal dikarenakan pekerja perempuan setelah pulang bekerja lebih memperioritaskan waktunya untuk mengurusi rumah tangga.

3. Waktu disediakan sangat sempit, dikarena perusahaan dianggap terganggunya proses produksi jika mengunakan waktu yang lama.

Penyuluhan ditargetkan agar materi yang disampaikan oleh pelaksana kegiatan tersampaikan dengan baik kepada peserta perempuan. Pelaksana mengukur target kegiatan ini dengan cara memberikan pre-test dan post-test kepada peserta. Jumlah peserta yang mengisi kuisioner hanya 45 orang dari 50 . Sebaran soal tes terdiri dari 30 pekerja laki-laki dan 15 pekerja perempuan. Hasil dari tes disajikan pada tabel 1.

Tabel 1. Hasil Pre-Test dan Post-Test

\begin{tabular}{|c|c|c|}
\hline & Pre-Test & Post-Test \\
\hline $\begin{array}{l}15 \text { pekerja } \\
\text { Perempuan }\end{array}$ & $\begin{array}{l}53.33 \% \text { tidak dapat } \\
\text { menjawab dengan baik }\end{array}$ & $\begin{array}{l}80 \% \text { dapat menjawab } \\
\text { dengan baik }\end{array}$ \\
\hline $\begin{array}{l}30 \text { pekerja } \\
\text { Laki-laki }\end{array}$ & $\begin{array}{l}40 \% \text { tidak dapat } \\
\text { menjawab dengan baik }\end{array}$ & $\begin{array}{l}86.67 \% \text { tidak dapat } \\
\text { menjawab dengan baik }\end{array}$ \\
\hline
\end{tabular}

Sumber: Data Primer

Tabel 1 dapat dilihat bahwa materi yang disampaikan oleh pelaksana, tersampaikan dengan baik, tetapi bukan terhadap peserta pekerja perempuan. Terbuki dari prosentasi menjawab post-test oleh pekerja laki-laki jauh lebih baik dibandingkan dengan pekerja perempuan.

Isian pertanyaannya terkait dengan peraturan yang lebih khusus mengenai hak pekerja perempuan. Hasil dari ini menggambarkan bahwa pengetahuan pekerja perempuan atas pentingnya perlindungan hak perkerja perempuan cukup rendah. 


\section{JURNAL ABDIMAS UBJ}

Pemahaman pekerja laki-laki jauh lebih baik, menunjukkan perlu adanya keterlibatan laki-laki dalam mendukung pekerja perempuan dalam menuntut hak-haknya yang belum dipenuhi oleh pihak perusahaan. Apalagi perwakilan Serikat Pekerja dalam perusahaan ini didominasi oleh laki-laki.

\section{Pemenuhan Hak pekerja Perempuan di PT. PAS, Bekasi}

Berdasarkan hasil pelaksanaan di atas bahwa secara normatif, PT. PAS telah memenuhi hak pekerja perempuan sesuai dengan undang-undang. Ini dapat dilihat dalam perjanjian Kerja Bersama antara pekerja dan PT. PAS. Hanya saja, perjanjian ini masih terdapat kekurangan di mana ada beberapa yang belum diatur secara jelas seperti:

1. Perpanjangan waktu cuti melahirkan,

2. Jumlah kalori yang berhak didapatkan oleh pekerja perempuan yang bekerja malam hari,

3. Jaminan kendaraan perusahaan untuk antar dan jemput bagi pekerja perempuan yang bekerja dari pukul 23.00-05.00,

4. Jaminan pekerja yang cuti hamil, melahirkan, dan keguguran tidak dipindahkan dari jabatan dan posisi kerjanya semula.

Selain itu, aturan pelaksanaan lanjutan dalam Perjanjian Kerja Bersama mengatur lebih rinci terkait hak pekerja perempuan sehingga semakin banyak persyaratan yang harus dipenuhi pekerja untuk mendapatkan hak tersebut. Perjanjian Kerja bersama ini akhirnya menjadi kendala bagi pekerja untuk dipenuhi haknya oleh perusahaan. Adapun kendalanya sebagai berikut:

1. Pengajuan cuti haid harus ada surat dokter yang telah bekerja sama dengan perusahaan.

2. Pengajuan cuti hamil, melahirkan, dan keguguran harus ada keterangan dokter dan akte perkawinan. Berkaitan dengan akter perkawinan, bahwa hak Cuti melahirkan bagi pekerja perempuan tidak berlaku bagi perkawinan yang tidak sah.

3. Pekerja perempuan yang bekerja malam hari tetap mendapatkan makanan tambahan, namun hanya 1 sachet susu, sedangkan mengacu dalam Kepemenakertrans No. Kep 19/224/MEN/2003 sekurang-kurangnya harus terpenuhi 1400 kalori.

\section{Dampak dan cara menyelesaikan permasalahan terhadap pekerja perempuan yang tidak terpenuhi hak-haknya oleh perusahaan}

Dampak yang langsung dirasakan oleh pekerja perempuan ketika tidak terpenuhi hak-haknya oleh perusahaan sebagai berikut:

1. Sangat berbahaya bagi pekerja hamil jika terpapar kandungan kimia atau radiasi dalam lingkungan produksi sehingga dapat menyebabkan cacat janin hingga kematian pada janin. 


\section{JURNAL ABDIMAS UBJ}

2. Tidak diberikannya cuti haid, hamil, dan melahirkan kepada pekerja perempuan, berdampak terganggunya organ reproduksi perempuan.

3. Tidak diberikannya waktu untuk menyusui akan berdampak langsung pada kebutuhan makan bayi-bayi pekerja perempuan.

4. Tidak terpenuhi antar jemput bagi pekerja perempuan yang bekerja malam hari, berisiko/berpotensi terjadinya pelanggaran asusila dan kejahatan terhadap pekerja tersebut.

Dampak tersebut akan dirasakan langsung oleh pekerja perempuan, jika hak-haknya tidak terpenuhi oleh pihak perusahaan. Selain itu juga, hal tersebut menyebabkan terjadinya perselisihan antara pekerja dan perusahaan. Berkaitan dengan perselisihan atas hak-hak pekerja perempuan yang belum dipenuhi, maka masuk dalam kategori Perselisihan Hak. Perselisihan tersebut dapat diselesaikan oleh pihak pekerja maupun perusahaan yang diatur secara normatif dalam Undang-Undang Nomor 2 Tahun 2004 tentang Penyelesaikan Perselisihan Hubungan Industrial (PPHI). PPHI dapat dilakukan antar para pihak (pekerja dan perusahaan), hingga ke pengadilan. Sebelum proses tersebut, ada tahap-tahap yang harus dilalui terlebih dahulu oleh pekerja jika terjadi perselisihan, yakni:

\section{Proses Bipartit}

Proses ini merupakan proses perundingan yang dilakukan antara pekerja dan perusahaan dalam menyelesaikan perselisihan hubungan industrial yang terjadi. Proses ini dapat dimanfaatkan oleh pekerja untuk menyampaikan kehendak/keinginan pekerja terkait dengan hak-hak pekerja, khususnya hak pekerja perempuan yang belum terpenuhi.

\section{2. $\quad$ Proses Tripartit}

Proses ini dilakukan setelah terjadi kegagalan dalam proses bipartit. Tripartit merupakan proses perundingan yang dilakukan antara pekerja dan pihak perusahaan melalui musyawarah yang ditengahi oleh pihak yang netral, dalam hal ini bisa dari mediator pemerintah yang berasal dari Suku Dinas Tenaga Kerja dan Transmigrasi di wilayah tempat pekerja bekerja. Proses ini dapat menghasilkan 2 (dua) hal. Pertama, jika mencapai kesepakatan, maka dibuatkan perjanjian bersama. Sedangkan, tidak terjadi kesepakatan maka Pemerintah mengeluarkan surat himbauan tertulis kepada pihak-pihak.

\section{Proses Peradilan}

Bagi pihak yang menolak hasil tripartit tersebut, maka pihak tersebut dapat melanjutkan perselisihan tersebut di Pengadilan Hubungan Industrial (PHI). Pihak pekerja/perusahaan dapat mengajukan gugutan terkait dengan masalah yang diperselisihkan. Lamanya proses ini menurut UUK Pasal 103 paling lama 50 (lima puluh) hari kerja. Bagi perselisihan hak, penyelesaikan di Pengadilan Hubungan Industrial merupakan peradilan tingkat pertama, dan pada tahap akhir (kasasi) di Mahkamah Agung.

\section{Simpulan dan Rekomendasi}

Dari kegiatan pengabdian kepada masyarakat ini, maka kesimpulannya adalah: 


\section{JURNAL ABDIMAS UBJ}

1. Materi penyuluhan dalam kegiatan pengabdian ini tersampai dengan baik terhadap pekerja perempuan, akan tetapi pemahaman pekerja laki-laki jauh lebih baik. Pengetahuan tentang hak-hak pekerja perempuan tidak dibatasi hanya pada pekerja perempuan, pekerja laki-laki mestinya juga mengetahui hak tersebut, sehingga ketika pekerja perempuan dalam memperjuangan haknya, tetap didukung oleh pekerja laki-laki.

2. Hak pekerja perempuan di PT. PAS telah terpenuhi, namun pekerja perempuan masih keberatan dalam hal syarat-syarat yang harus dipenuhi oleh pekerja perempuan dalam mengajukan pemenuhan hak-hak tersebut yang tertuang dalam Perjanjian Kerja Bersama sehingga pelaksanaannya belum sesuai dengan UUK. Sedangkan hak pekerja perempuan yang belum terpenuhi dengan baik oleh perusahaan akan berdampak pada terganggunya fungsi reproduksi pekerja perempuan yang berakibat pada produktivitas perusahaan juga menjadi terganggu. Selain itu juga hal ini memicu terjadinga sengketa dalam hubungan industrial.

Rekomendasi yang penulis berikan dalam pelaksanaan pengabdian agar lebih baik ke depan, adalah:

1. Pada pelaksanaan pengabdian ini dalam tema hak pekerja perempuan, keterlibatan pekerja laki-laki dalam penyuluhan ini penting dalam mendukung dan turut memperjuangan hak pekerja perempuan yang belum terpenuhi.

2. Perusahaan baiknya memenuhi hak mereka. Pemenuhan tersebut, semestinya disadari bahwa hal itu tidak mengurangi profit bagi perusahaan, sebaliknya jika tidak dilindungi maka otomatis daya produksi perusahaan akan mengalami penurunan akibat dampak yang dialami pekerja perempuan seperti sakit bahkan meninggal akibat gangguan fungsi reproduksinya.

\section{Ucapan Terima Kasih}

Penulis tidak lupa mengucapkan banyak terima kasih kepada Universitas Bhayangkara Jakarta Raya yang selalu memberikan dukungan dan dana untuk terselenggaranya kegiatan ini.

\section{DAFTAR PUSTAKA}

Asyhadie, Z. 2007. Hukum Kerja Hukum Ketenagakerjaan Hubungan Kerja. Jakarta: Raja Grafika, 2007.

Febriani, R. N. (2 Maret 2017). Buruh Tuntut Pemenuhan Hak Pekerja Perempuan. Koran Online Pikiran Rakyat.

<http://www.pikiran-rakyat.com/bandung-raya/2017/03/02/buruh-tuntut-pem enuhan-hak-pekerja-perempuan-395029>, diakses tanggal 4 Juni 2017.

Johanes. (2 Mei 2013). Buruh Tuding PT. Musim Mas Tekan Pekerja Perempuan. Koran Online Tribunnews Pekan Baru. 


\section{JURNAL ABDIMAS UBJ}

<http://pekanbaru.tribunews.com/2013/05/02buruh-tuding-pt-musim-mas-tekan-pekerja perempuan>. Diakses tanggal 10 Juni 2017.

Putusan Mahkamah Agung Nomor 94K/Pdt.Sus/2013.

Remmelink, J. 2003. Hukum Pidana. Jakarta: Gramedia Pustaka Utama.

Republik Indonesia. Hak Asasi Manusia.Undang-Undang Nomor 39 Tahun 1999.

Republik Indonesia. Undang-Undang tentang Ketenagakerjaan. Undang-Undang Nomor 13 Tahun 2003

Republik Indonesia. Undang-Undang tentang Penyelesaian Hubungan Industrial. Undang-Undang Nomor 2 Tahun 2004.

Suryadi, K. (2016). Pengembangan Industri Berkelanjutan di Asia.

$<$ www.oneasia.unpad.ac.id/Pengembangan-Industri-Berkelanjutan-Di-Asia.pdf $>$.

Diakses tanggal 9 Juni 2017. 